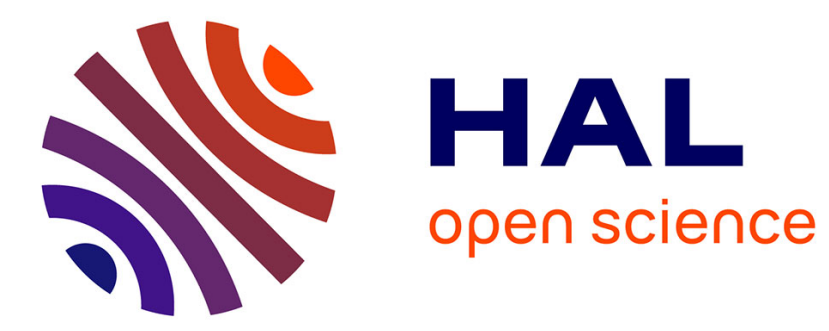

\title{
The EU Conciliation Committee
}

Anne Rasmussen

\section{To cite this version:}

Anne Rasmussen. The EU Conciliation Committee. European Union Politics, 2008, 9 (1), pp.87-113. 10.1177/1465116507085958 . hal-00571758

\section{HAL Id: hal-00571758 \\ https://hal.science/hal-00571758}

Submitted on 1 Mar 2011

HAL is a multi-disciplinary open access archive for the deposit and dissemination of scientific research documents, whether they are published or not. The documents may come from teaching and research institutions in France or abroad, or from public or private research centers.
L'archive ouverte pluridisciplinaire HAL, est destinée au dépôt et à la diffusion de documents scientifiques de niveau recherche, publiés ou non, émanant des établissements d'enseignement et de recherche français ou étrangers, des laboratoires publics ou privés. 


\section{EUP}

European Union Politics

DOI: $10.1177 / 1465116507085958$

Volume 9 (1): 87-113

Copyright@ 2008

SAGE Publications

Los Angeles, London, New Delhi and Singapore
KEY WORDS

- co-decision

- Conciliation Committee

- European Parliament

\section{The EU Conciliation} Committee

\section{One or Several Principals?}

\section{Anne Rasmussen}

European University Institute, Italy

\section{ABSTRACT}

Since the introduction of the co-decision legislative procedure, the EU has had the possibility to resort to a Conciliation Committee made up of representatives from the European Parliament and the Council to reconcile differences between the two bodies. This article assesses whether the members of this committee have an incentive to take advantage of their ability to present take-it-or-leave-it offers to their parent bodies by examining whether they are representative of their full body and/or whether they represent other interests inside or outside their legislative body. It concludes that the EU Conciliation Committee is generally representative of its parent bodies and that the option to go to conciliation is not a risky tool for them to reach agreement. 
The European Union has developed considerably since its inception and has increasingly grown to resemble a domestic political system. A crucial step in this process was the introduction of the bicameral, co-decision legislative procedure, which enables the European Parliament (EP) and the Council to meet directly to resolve disagreements in a Conciliation Committee. This committee can exert a significant influence on the legislative files it reconciles which typically affect the daily lives of millions of EU citizens. Hence, it has the potential to suggest compromises that the Council and the EP cannot amend but have to accept, unless they do not want any new legislation at all. The members of the Conciliation Committees are not free to do what they want, but must act within an institutional framework. However, these institutions do not determine their behaviour because the entire rationale of delegation is to give the delegates a certain freedom of manoeuvre to enable them to reach a compromise. Hence, the question of who serves on these committees is important and the legislative bodies have an interest in appointing delegates whose loyalty lies in defending their position.

Whether they actually succeed in doing so has not been examined in the very sparse literature on EU Conciliation Committees. This paper conducts the first study on the composition of EU Conciliation Committees analysing the actual policy positions of the conciliation delegates. General ideological scores are used to measure policy positions, and data are included on all the EP conciliation delegates in the first five years after the entering into force of the Amsterdam Treaty, i.e. from 1 May 1999 to 30 April 2004. The idea is that conciliation members can be seen as agents who may serve different principals, only one of whom is their legislative body as a whole. The key question that will be answered is thus: In line with whose interests are the conciliation delegations set up?

I examine only whether the EP appoints conciliation delegates whose loyalty lies in defending the position of their legislative body. It can be assumed that the Council delegation has no incentive to try to move legislative outcomes away from what Council would want. Firstly, each member state is represented in the delegation. Secondly, the members of the delegation are not politicians (except one ${ }^{1}$ ); they are generalist-oriented diplomats (socalled 'deputy permanent representatives'), who are not loyal to a particular sector, but work directly for the foreign offices of the member states. Thirdly, there is no question of the Council appointing either an extreme or a moderate delegation according to its strategy in a given circumstance since it is always represented by the same people in conciliation. The Council delegation is in many ways the Council. Instead, I focus on the EP's delegation here. With a fixed Council delegation, there is no strategic need for the EP to adapt the composition of its delegation on a case-by-case basis to that of the Council. 
Neither is it interested in always appointing an extreme delegation in order to counterbalance the Council, because Members of Parliament (MEPs) are likely to react negatively if they were to find out that conciliation delegates were defending more extreme points than those agreed in the second reading amendments of the EP. Instead, the EP seeks to appoint a delegation as representative of the plenary as possible. This minimizes the risk that the EP plenary will subsequently reject the conciliation text, which might threaten the credibility of the EP as a responsible partner to the Council in the EU policy process.

The study shows that the EP's delegation is representative in practice. Hence, at the same time as the EP party groups have delegates close to their median position, the delegation is composed in such a way as to be in line with the interests of the full body. Overall, therefore, the conclusion is that going to conciliation rarely involves legislative bodies running the risk that the delegates will act contrary to the interests of their overall bodies. I start by providing additional information about the EU Conciliation Committee and reviewing the existing literature about it. Then I set out the theoretical framework, discuss methodology and data and perform the empirical analysis.

\section{The EU Conciliation Committee}

The 15 areas of Community activity with co-decision in the Maastricht Treaty have been extended with each new treaty. Currently, the procedure applies to 40 legal bases of the Treaty and to such crucial policy areas as the internal market, research policy and anti-discrimination measures. According to Article 251 of the Treaty, the EU Conciliation Committee is convened in the co-decision legislative procedure if the Council cannot find the necessary majority to accept all the second reading amendments of the EP. ${ }^{2}$ In other words, if the legislative procedure has completed two readings and there is still no agreement between the EP and the Council, the third reading may still be proceeded towards. Here, the Council and the EP delegate responsibility to members from their bodies to reconcile differences in a Conciliation Committee. This committee consists of an equal and fixed number of representatives from the Council and the EP (15 in the period examined). As stated above, the Council delegation is fixed and includes a representative from each member state. In the EP, the rules assign quotas to each political group in the delegation, which largely reflect the composition of the EP but leave it up to the groups themselves to decide who they will send to conciliation (European Parliament, 2005: rule 64). They typically send people from the relevant standing committee, and it is customary to appoint the 
relevant committee chairperson, the rapporteur and the three EP vicepresidents responsible for conciliation as delegates. For the Conciliation Committee to reach agreement, a qualified majority of the Council delegation and a majority of the EP delegation have to support the deal, ${ }^{3}$ which then goes to a final vote in the Council and the plenary of the EP. At this final stage, a qualified majority is again needed in the Council, whereas a simple majority (i.e. a majority not of all members of the EP, but merely of those present during the vote) is sufficient in the EP. In both legislative bodies, this final vote is a so-called 'closed' vote, which means that the legislative bodies cannot amend the Conciliation Committee compromises but have to accept them as a whole, the alternative being no new legislation at all.

Conciliation is not always resorted to because efforts are made to save time and staffing resources by concluding earlier in the legislative process. However, the significance of having a Conciliation Committee lies not merely in its actual but in its potential use, and this possibility of going to conciliation is likely to induce actors to act differently in the initial stages of the procedure than they would otherwise do. For example, a former head of the EP Conciliation Secretariat has mentioned that the possibility of going to conciliation in the EU 'casts a shadow backwards over the whole codecision procedure' (Shackleton, 2000: 330).

In a recent review of the field of EU legislative politics, McElroy (2007: 187) underlines how 'the institution of the conciliation committee remains largely unstudied, no doubt in large part due to its comparative youth, but it offers a fruitful avenue for further analysis in the future, both qualitatively and quantitatively'. None of the existing studies has systematically examined Conciliation Committee composition.

Some address related issues. Garman and Hilditch (1998), for example, conducted an initial study to show how the conciliation processes work. They pointed out how the practice has been established of holding informal meetings in advance of the formal conciliation meetings, and how these have been decisive in ensuring that agreements could be reached between the colegislators. By contrast, Napel and Widgren (2003) and König et al. (2007) were interested in whether the EP or the Council was likely to have more influence on the legislative outcome when a file goes to conciliation. Napel and Widgren (2003) found that, even though the Council and the EP are in a symmetrical position in the legislative procedure, the Council is still the dominant legislative body. The Council's higher majority requirement therefore makes it typically the player with the position closest to the status quo, which gives it an advantage in its negotiations with the EP. König et al. (2007) conducted the first statistical analysis of 'who wins?' in the conciliation 
processes using data from May 1999 to July 2002. Their findings show that the EP won more often than the Council in their cases, but the Council was more successful in multidimensional disputes with the EP. König et al. (ibid) also demonstrate that actors located close to the status quo have a bargaining advantage, that the Council benefits when there is low internal cohesion in the EP, and that the Commission is not an irrelevant actor in the conciliation processes.

Moreover, some studies point to the importance of the appointment rules, but do not have systematic data on the policy positions of the conciliation delegates. Tsebelis and Money's (1997) study of bicameralism, for example, sets up a formal model predicting the power of Conciliation Committees in the systems where they exist. It shows that the legislative outcomes can be expected to be a function of the composition of these committees and the bicameral restrictions. Also, in a recent article about how institutionally constrained the EU conciliation delegates are (Rasmussen, 2005), I point to the importance of the composition of the EP delegation and include assessments of the likelihood of it being representative based on the appointment rules. In my view, fairly effective constraints that are in place within both the Council and the EP ensure that representative conciliation delegates are appointed and act in accordance with the wishes of their parent bodies.

However, whereas this representativeness rule assigns quotas to each political group, it does not in itself ensure that only members with certain ideological views are appointed, as, for example, the delegation-appointing rule of the US House of Representatives is supposed to do. Here the Speaker of the House is obliged to appoint no less than a majority 'who generally supported the House position' (Jewell and Patterson, 1986: 169). So we need to know whether or not the chamber in practice appoints representative delegations and/or whether or not the conciliation delegates represent other principals.

Research based on the policy positions of MEPs has recently been conducted on the composition of the standing committee of the EP. McElroy (2006) has shown that the committee system is generally proportional to the EP groups as well as to the share of members from different member states. Moreover, she shows that committee members are not ideologically different from the full plenary. Whitaker (2005) has shown that the MEPs' ideological position on the committees typically conforms to that of their national party delegation.

We know that most conciliation delegates originate from these standing committees (Rasmussen, 2005: 1031), which might lead us to expect that their respective levels of representativeness is similar. However, there are also 
certain differences between the two that may make it somewhat harder to ensure representativeness in the conciliation delegation than in the standing committees. First, the difference in size between the standing committee and conciliation delegations is likely to make it harder for party leaders to pick a fully representative delegation to the conciliation delegation than to the standing committees. Hence, whereas the size of the conciliation delegations was set at 15 in the period examined, the average size of the standing committees was more than three times as large. When a party group has just one or two delegates in conciliation, it may not be able to find members who represent the interest of the group as a whole. Second, even if it can, other concerns might lead it to appoint a delegation that is not fully representative. It is also likely to ensure that the members appointed from the standing committees have the necessary experience and expertise to conduct negotiations with the Council. Third, these practices mean that certain institutional figures within the EP (i.e. the three vice-presidents responsible for conciliation, the rapporteur and the chairperson of the relevant standing committees) are always appointed as conciliation delegates irrespective of their policy position. They are supposed to represent the leadership, but this does not mean that their individual policy positions are necessarily representative of the EP.

We therefore cannot simply assume that the EP conciliation delegation is representative. This also emerges from interview evidence, where one practitioner from the EP explained that 'you can find yourself with certain interests more heavily represented than others', especially because 'people who are particularly interested in the file will make their voice known inside their group'. Also an administrator from the Commission pointed out: 'There is a discrepancy in the Treaty between the delegation of the Council, which is absolutely representative of the Council, whereas the delegation of the Parliament is not necessarily fully representative of the Parliament ... The delegation can be skewed in favour of a nationality or an interest group'. ${ }^{4}$

\section{Multiple conciliation principals?}

To predict which potential principals the conciliation delegations are likely to represent, I here apply the dominant approaches to the study of the US Congress, i.e. informational, distributional and party theory. Each theory makes different predictions about the composition of the conciliation delegation and thus ultimately about whether conciliation delegations can be expected to be representative of their chamber or not. Expressed differently, they draw attention to the different principals (i.e. the chamber, the client interests of the standing committees and the parties) of whom the conciliation 
delegates may be agents (Maltzman, 1997). Moreover, I have added the possibility that conciliation delegates are representing their fellow national MEPs within the chamber.

We know from principal-agent theory how delegation problems can arise when the preferences of the agents deviate from their principal and when the agent enjoys informational advantages (Kiewiet and McCubbins, 1991; Strøm, 2003). Here, I examine whether the first of these problems arises if the delegates represent other interests (or, in the principal-agent terminology, other principals), inside or outside the legislative body, that diverge from the chamber opinion. Figure 1 gives an overview of the empirical implications of the different theoretical perspectives. It illustrates what they would expect the distribution of preferences of the conciliation delegates and their parent bodies to look like and where they would expect their medians to be located (vertical lines). Although only informational theory was originally tested on Conciliation Committees, the logic behind distributional theory and party theory can be relatively easily extended to Conciliation Committees as recent US literature has done (Rybicki et al., 2003). However, some adaptation of the theories is necessary in order to apply them to the EP.

The first theory is the informational view of congressional organization (Krehbiel, 1991), which would expect Conciliation Committees to be in line with their chamber. This perspective argues that legislatures are majoritarian, i.e. a majority of the legislature controls policy and procedural decisions. Moreover, the actors are uncertain about the relationship between the policies they choose and their longer-term outcomes. Therefore, legislative organization is designed in such a way that uncertainty is reduced with 'rules and procedures that provide incentives for individuals to develop policy expertise and to share policy relevant information with fellow legislators' (Krehbiel, 1991: 5). This means that negotiations are left to decision-makers with considerable knowledge in particular issue areas and, applied to the conciliation sphere, a large proportion of the delegates would be expected to come from the relevant standing committee that dealt with the file before conciliation. At the same time, though, members of the standing and Conciliation Committees are ensured to be representative of their parent bodies, i.e. the median position of the conciliation delegation is similar to the median position of the chamber. As Figure 1 shows, two types of representative committees can be distinguished. Either the committee can be composed in such a way that it has similar preferences to the chamber, or it can consist of heterogeneous preference outliers that are more extreme than the average chamber member but that balance each other out (for example, a similar share of environmentalists and industrialists in a conciliation about $\mathrm{CO}_{2}$ emissions). Moreover, institutional constraints are in place that make sure that legislators 


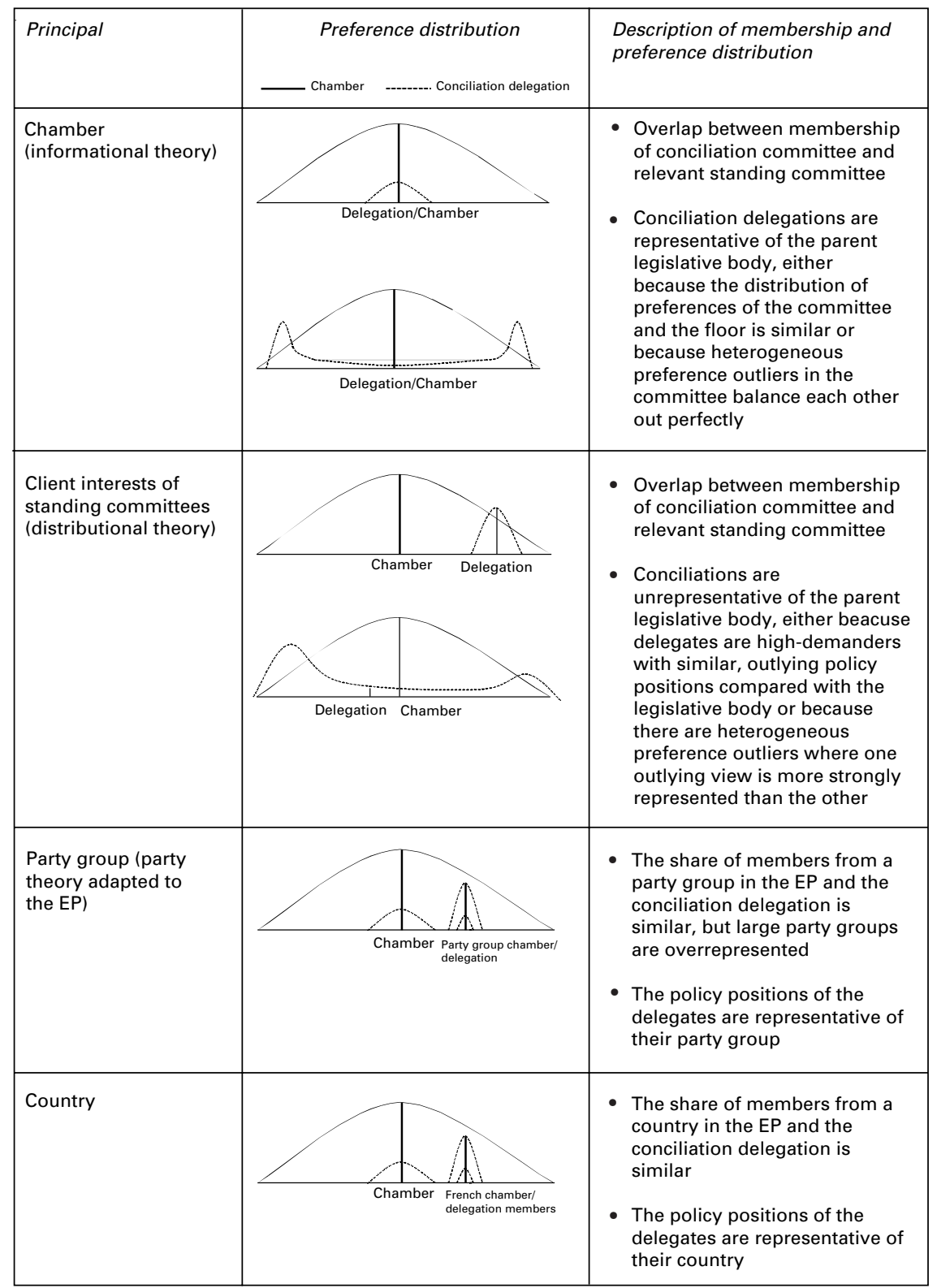

Figure 1 The four potential principals.

Notes: The illustrations of the observable, empirical implications of informational, distributional and party theory are inspired by Maltzman (1997). 
on committees act in accordance with the opinion of the chamber. In this way, everybody 'gains from specialization'.

Secondly, following the logic of the distributional view of congressional organization (Weingast and Marshall, 1988; Shepsle and Weingast, 1987a, 1987b), Conciliation Committees should be in line with those standing committees that previously dealt with a given file, and therefore ultimately with the external client interests of these committees. This perspective sees the main rationale underpinning the legislative organization to facilitate 'gains from trade' between members in an uncertain bargaining environment. This is done by developing institutions that stabilize their interaction, for example a committee system that gives members with a special interest in particular subject areas disproportionate control over the relevant policy, in order to facilitate that everybody gains from trade. Hence, members are given the chance to select seats on the standing committees in accordance with their particular (typically constituency) interests, and the members of the standing committees dominate the Conciliation Committees in their area (Shepsle and Weingast, 1987a, 1987b). If we apply the logic of distributional theory to the area of Conciliation Committees, this would mean that conciliation delegations, like the standing committees, consist of a greater number of so-called 'high demand' members than the chamber as a whole and are relatively unconstrained. As Figure 1 shows, two types of outlying conciliation delegation can be distinguished. It can consist either of homogeneous outliers (for example in a conciliation on education policy where all members are more supportive of this type of policy than the average chamber member) or of bipolar outliers (for example in a conciliation on labour market policy where there are both employer and employee interests) where the net result is an unrepresentative conciliation delegation because one type of interest is more dominant than the other. The co-decision procedure does not apply to all the areas of EU pork barrel politics, but it does apply to distributive policy areas such as research and education policy and even certain questions relating to the structural funds.

Thirdly, the logic of party theory (Cox and McCubbins, 1993, 1994) would dictate that the parties act as the principals of the conciliation delegates. According to Cox and McCubbins (1994: 226), '[t]he majority party caucus adds another layer of structure and process onto the committee structure studies by Shepsle-Weingast'. Thus, members are bound together in parties that give them benefits, above all the value of the 'party label' when running for re-election. In return, they support the majority party's control over key elements of the chamber's structure, which leads the chamber to adopt 'policies that, on average, benefit majority party members more than minority party members' (Cox and McCubbins, 1994: 226). Cox and 
McCubbins (1993: 2) explain how the committee system is 'stacked in favour of majority party interests'. Party leaders ensure that their own delegates support the party position by having either a representative delegation of the party on the committee or an extreme one whose views are directly contrary to those of the minority in order to counterbalance the minority's views. In any case, the net result is a committee whose median is situated on the majority party's side of the chamber median. This is reinforced by the fact that the majority party is typically overrepresented in committees compared with the full House. This is possible because in practice the total number of seats of a committee and the allocation of seats between parties are determined by the House majority leadership (Davidson and Oleszek, 2002: 205).

Applying party theory from the US Congress to the EP may seem inappropriate because of the different nature of the party system and the party groups. Most importantly, MEPs belong not only to their party group in the EP but also to their national party, which in terms of re-election makes them less dependent on the European party groups than the US members are on theirs. However, European party groups still play a crucial role in securing assets for their members because they select the crucial spokespersons for each file (so-called rapporteurs), control committee seat allocations, and so on. According to Hix et al. (2006: 496), 'transnational parties in the European Parliament help national parties and MEPs structure their behavior in much the same way as parties do in the U.S. Congress'. Hence, members can still be expected to have clear incentives to follow the party group line. However, owing to the different nature of the party system (two-party versus multiparty), it is not possible to speak of a majority party that controls the parliamentary agenda and policies. In certain circumstances one might be able to speak of a majority coalition between the two large party groups: the PPE (European People's Party) and the PSE (Party of European Socialists). However, this coalition forms only ad hoc for procedural purposes and consists of legislators with policy positions that are far from coherent.

The PPE and PSE might be able to use their majority of votes to ensure that they are overrepresented in the conciliation delegation, just as the US majority party does in the House. However, they are constrained by the requirement that the formula for the composition of the conciliation delegation for a given term be adopted by the presidents of all party groups of the EP and that it correspond to the political composition of the EP. It is still possible that the large groups are able to collude and ensure that they are somewhat overrepresented in the delegation. Hence, because of the different size of the delegation and the plenary it may not be possible to ensure strict proportionality in the formula, which leaves some scope for negotiation of the exact quotas. 
However, whereas the large EP groups may be overrepresented like the US majority party in the House, the US party theory prediction that political groups should be able to strategically appoint members with extreme ideological positions to counterbalance the remaining parties may not hold true because of the character of the multi-party system in the EP. It is not always the case that the party groups divide along lines of clear support and opposition on a given issue. Even if they do, those on the same side would have to be able to coordinate to ensure a given ideological composition of their conciliation delegates as a whole, and there is no evidence that they are. Instead, the most reasonable expectation is that the party groups seek to appoint members that are representative of the group.

Finally, Conciliation Committees may have responsibility to a fourth principal, namely the regional entity that they represent, i.e. the member state. Hence, being a union of states, it cannot be ruled out that a member state is a somewhat coherent entity with preferences it seeks to further through exchanges with other member states. In such a perspective, national members of the EP can be seen as representatives of different national interests. Member states could act as principals to Conciliation Committees by influencing their members and their agendas. For example, recent literature has pointed out how the national representations in Brussels often lobby their members to defend certain views within the EP (Farrell and Héritier, 2003: 28). If countries were important as principals, one might expect that the median position of conciliation members from a country would be similar to the median position of all the members from that country in the plenary. Moreover, it could be that the proportion of members from different countries in conciliation and the full plenary is similar. However, for several reasons neither of these two outcomes is very likely in practice in the EP. First, in contrast to the Council, there are no rules for ensuring geographical representativeness in the EP's conciliation delegation. Second, there are no national coordinating bodies of MEPs across party groups that could pick members with certain policy positions to act as conciliation delegates. The members from the relevant standing committees typically serve irrespective of whether they have extreme policy positions vis-à-vis their fellow citizens. I would therefore expect any coherence found between the position of conciliation delegates from a given country and all delegates from that country in the plenary to be random.

These four different principals are not mutually exclusive. Particular client interests of the standing committees may overlap with party group interests, MEPs may align with both their fellow citizens and the EP as a whole in certain cases, and so on. The analysis should therefore be seen as an examination not merely of whether but also of the extent to which different principals matter. ${ }^{5}$ 


\section{Data and measurements}

In order to perform the analysis, a data set was gathered from official sources and the conciliation archives of the EP. ${ }^{6}$ It includes information on members of the EP in its fifth session (1999-2004), including 1260 full and 954 substitute delegates on the 86 Conciliation Committees within the period. The tests for the different principals always involve two questions: (a) is a certain principal (standing committee, party group, group of country members in the EP) overrepresented or underrepresented, and (b) are the policy positions of the delegates representative of a given principal?

To measure policy positions I use the NOMINATE scores that Hix and Noury calculated for the EP. NOMINATE scores were originally developed by Poole and Rosenthal (1997), and they collapse the vote splits in all the roll calls of a given Congress or parliamentary term into a small number of dimensions. This makes it possible to extract ideal point estimates for each member of the legislative body. ${ }^{7}$ Even though NOMINATES exist for more than one policy dimension, I use the scores for the first dimension because they typically explain almost all the variation in the voting records. They have been argued by Hix et al. (2006) to represent an ideological left/right scale.

Problems might arise from using action-based measures such as NOMINATES to measure policy positions. It has been pointed out that the voting behaviour of legislators seen in NOMINATES may not be a simple reflection of their preferences, but may also be influenced by other factors such as legislative institutions and the opinion of other actors both inside and outside the EP. Moreover, a substantial number of roll-call votes used for the estimates are not important votes taken in procedures where the EP has a lot of power, but are of a more symbolic nature. Finally, the votes taken by roll call used for the NOMINATE scores might not be a representative sample of all the votes that take place within the EP (Carruba et al., 2006).

Hoyland (2006) has shown that, even though ideology scores are generated from all kinds of roll-call votes, not just important ones, they are not biased. Hence, a new set of scores generated from only important votes show similar results to the ones found with the existing scores. It is clear that the criticism of recorded votes perhaps not being representative of all votes in the EP remains, although it is less weighty here because the study attempts to put forward absolute statements not on the extent to which parties and standing committees, etc., are cohesive, but on the extent to which there are relative differences in the votes of the conciliation delegates and their various principals. Therefore, as long as conciliation delegates and non-conciliation members are relatively similar in the possible bias in NOMINATE scores, the relative differences can be assumed to represent differences in policy positions. 
A criticism that can be levelled at inferring bias from the preferences of the entire conciliation delegation of the EP is that many compromises are not really negotiated by these delegations as a whole. However, as I have shown elsewhere (Rasmussen, 2005), the negotiators from the parliamentary delegation are kept on a tight rein by the full delegation to which they have to report at regular intervals and from which they have to collect mandates during negotiations. Thus, precisely because these informal compromises reached in smaller forums have to be adopted by the conciliation delegations as a whole, one should not just look at the policy position of the key negotiators, but take the policy positions of all conciliation members into account.

\section{Empirical analysis}

\section{Chamber principal}

The empirical analysis starts by looking at the extent to which conciliation delegates have policy positions that are representative of their parent chambers (as informational theory would expect), by using three measures of ideological representativeness. First, I apply the Wilcoxon-Mann-Whitney nonparametric test for independent samples between the delegation and the chamber for each conciliation procedure. This measure shows that there were no significant differences between the conciliation delegations and the EP in any of the 86 conciliation cases. This is of course partly owing to the relatively small $n$ of each conciliation delegation. Secondly, therefore, I also use another possibility for measuring whether committees are composed of outliers, as suggested by Krehbiel (1991: 126); i.e. I examine the percentage share of members in each of the 86 procedures that were located between the chamber and Conciliation Committee NOMINATE medians. Hence, even though the illustrations of the empirical observable implications of the different theoretical perspectives in Figure 1 give examples of preference distributions, ultimately I am interested not in whether the preferences of the individuals of the two compared groups of MEPs are more or less dispersed but in whether the views of the pivotal, decision-making members in these groups are similar. Since decisions in the EP are taken by majority vote, I look at the medians of the compared groups. After calculating the percentage share of members in each of the 86 procedures that were located between the chamber and Conciliation Committee NOMINATE medians, I calculate the average share for the 86 procedures. The lower it is, the more representative the Conciliation Committee is on average. This measure also indicates high representativeness, since it was as low as 4.09 in the conciliation procedures 
in the period examined and could be an artefact of statistical chance. The third measure calculates the average numerical distance in the 86 procedures between the medians of the conciliation delegation and the chamber. The lower it is, the more representative the delegations are. Here it was as low as 0.0735 .

A check on committee jurisdiction, not unexpectedly, shows some variation between areas - ranging from 0.006 to 0.216 . However, despite their variation these average distances are not very high for any committee area. Moreover, committees from distributive areas do not necessarily have higher levels of bias than those from areas of more general interest. For example, the delegations originating from the agriculture and regional committees show very small average discrepancies, whereas those of delegations from other committee areas, for example industry, are higher. Official reports from the EP also confirm that the delegation is typically representative of the EP. For instance, one document states that '[d]espite the biotechnologies episode in March $1995^{8}$. . . confidence in the functioning of Parliament and in the representativeness of its delegation to the Conciliation Committee has not been impaired' (European Parliament, 1996: 4).

Moreover, having the three permanent members (the three vice presidents, the rapporteur and the relevant committee chairperson) in the conciliation does not affect the level of representativeness. Removing these members from the calculations does at first increase the level of preference bias. However, this might be simply because it changes the political balance in the composition of the delegation: removing these members in effect leads to underrepresentation of the PPE and PSE groups, which, not surprisingly,

Table 1 How representative are the conciliation delegations of a) the EP and b) the relevant standing committee?

Delegation and

Delegation relevant standing

and chamber committee

\begin{tabular}{|c|c|c|}
\hline $\begin{array}{l}\text { Average numerical NOMINATE distance between } \\
\text { medians in the } 86 \text { procedures }\end{array}$ & 0.0735 & 0.0699 \\
\hline \multicolumn{3}{|l|}{ Average percentage share of chamber members } \\
\hline located between medians in the 86 procedures & $4.09 \%$ & $3.40 \%$ \\
\hline Percentage share of the 86 procedures where the & & \\
\hline $\begin{array}{l}\text { Wilcoxon-Mann-Whitney test shows that the } \\
\text { difference is significant below the } .05 \text { level }\end{array}$ & $0.0 \%$ & $0.0 \%$ \\
\hline
\end{tabular}

Note: $N=$ chamber members and 1260 conciliation delegates in 86 conciliation committees. 
leads in turn to less representativeness of the plenary as a whole. Hence, in the period examined, two vice-presidents always came from the PPE group, one always came from the PSE group and most of the rapporteurs and committee chairs also came from these two large groups. Instead, I have checked whether removing the permanent members from a given party group's delegation moves its median ideologically closer to the chamber median.

The analysis shows that the average distances to the chamber median in the 86 procedures are very similar both for all party group delegates and for delegates excluding the permanent members. The results are largely the same whether I remove only the vice-president(s) or also the committee chairperson and rapporteur from the groups in cases where they hold these posts. In fact what is striking is that the average distance to the chamber median becomes even a little smaller for both party groups when their permanent members are ruled out of the calculation. Hence, these permanent members do not serve to pull the rest of its party members in conciliation closer to the chamber median. This does not contradict or support informational theory, which does not make any predictions about the likely level of preference bias of individual members compared with the rest of the delegates, but simply predicts that the preference bias in the delegation as a whole should be low, as indeed was the case in practice. However, appointing such specialists fits well with the predictions of informational theory in general. The rapporteur is likely to have a lot of expertise on the dossier, the relevant committee chairperson is also likely to be knowledgeable about the issue area, and the vicepresidents have expertise in conducting negotiations.

\section{Committee principal}

Owing to the good fit of informational theory, the predictive power of the distributional perspective, arguing that delegations should be in line with outlying standing committees, should be low. If we first examine how well the standing committees are represented, we find that there was a considerable overlap between the number of standing committees and their conciliation delegations in the period examined. Thus, 75 per cent of the full conciliation members were either full or substitute members of the relevant standing committee. Furthermore, if we include the three permanent members of the parliamentary delegation (i.e. the three vice-presidents responsible for conciliation) who are present no matter in which legislative area the negotiations are held, then the figure is as high as 92 per cent. ${ }^{9}$ However, as mentioned, this fits with both distributional and informational theory. 
Where the theories differ is in the second part of the test, i.e. what they expect the policy positions of the conciliation delegates to look like compared with their chamber. Unlike informational theory, distributional theory would expect the conciliation delegation to consist of preference outliers, just like the standing committees. Table 1 shows that the policy positions of the conciliation delegates are in fact similar to those of the standing committees of the EP. Thus, there are no significant differences between the NOMINATES of the conciliation delegates and of the relevant standing committees in any of the 86 procedures. Moreover, the average share of chamber members in the procedures located between the medians of the conciliation delegations and of the standing committees is even smaller than between the medians of the delegates and the chamber. However, there is no major divergence between the standing committees and the chamber in the first place, as distributional theory would expect. Instead, we have a situation where the median member of the chamber, the standing committees and the conciliation delegations are similar, which fits the predictions of informational theory.

\section{Party group principal}

Thirdly, I look at the extent to which the party groups act as principals of the conciliation delegations. First, I examine whether any party groups are over- or underrepresented. As mentioned, the balance between different party group members in conciliation is fixed in the formula agreed at the start of an EP term. To ascertain if the formula was biased, I calculated the expected number of conciliation delegates given the distribution of seats in the EP (row 3 in Table 2) and subtracted this figure from the actual distribution (row 2). As can be seen, the level of bias varies between the groups but is strongest in the PPE and PSE groups. It is clear of course that strict representativeness cannot be achieved because the fixed number of conciliation delegates (15) is not an exact divisor of the total number of EP members (626). However, this alone cannot explain the bias, because it would actually be possible to set up a delegation in which the average bias in numerical terms between the party groups was lower. Such a distribution is shown in row 5. Compared with the actual distribution, it would remove one seat from the PSE group and give a full seat to Europe of Nations, so that only Europe of Democracies and Diversities and the non-attached would share a seat. In short, it is likely that the big groups used their power to agree on a formula that overrepresents themselves somewhat in conciliation. Conversely, the smaller parties were underrepresented, a situation that was aggravated by the reluctance of the smaller groups to appoint members for their quota at 
the beginning of the period (European Parliament, 2001a: 16). A calculation involving all conciliation delegates during the fifth term shows that the differences in the shares of the PPE, PSE, Europe of Nations and non-attached members in conciliation compared with their shares in the full legislative body were statistically significant, whereas they were not significant for the other groups.

Even though this article does not concern the current EP term, it is interesting to point out here that in the EU27 the large groups are even more overrepresented because the extreme right and left groups (i.e. the Identity, Tradition and Sovereignty group and the Independence/Democracy group) plus the non-attached have been excluded from conciliation work altogether. This means that both the PPE and the PSE groups have one seat more than they would have had if strict proportionality between the plenary and the delegation had applied, and all the other groups except the liberals are underrepresented.

Second, I proceed from examining representation to look at whether the delegates of party groups have similar policy positions to their groups. Because relatively few members from the smaller groups in the EP sit on Conciliation Committees, I focus on the PPE and PSE party groups. I again use the Wilcoxon-Mann-Whitney test, which shows that there were significant differences between the policy positions of a party group's conciliation delegates and the rest of the group only in four conciliation procedures in the PPE group and in two procedures in the PSE group $(4.7 \%$ and $2.3 \%$ of the total number of conciliation procedures, respectively; see Table 3). I also calculated the average numerical NOMINATE distance in the 86 procedures between the medians of party group members in the delegation and all party group members in the chamber. The smaller this average distance is, the more representative a party group's conciliation delegates are of the party group. Moreover, if party delegates hold similar positions to their party group as a whole, I would expect the NOMINATE distance between them and their group to be smaller than between them and all EP members.

This is clearly the case in Table 3. On average there is a lot of similarity between the NOMINATE medians of the party group as a whole and those members of the group that sat on the Conciliation Committees in the 86 procedures, whereas the distances between a party's conciliation delegates and the EP median are much larger. The distance between the full party group and its members is smallest in the PPE group, but it is small for both political groups.

In short, the predictions of the adapted version of US party theory about the composition of the conciliation delegation performed well. There was a small overrepresentation of the two biggest groups in the fifth EP term and 


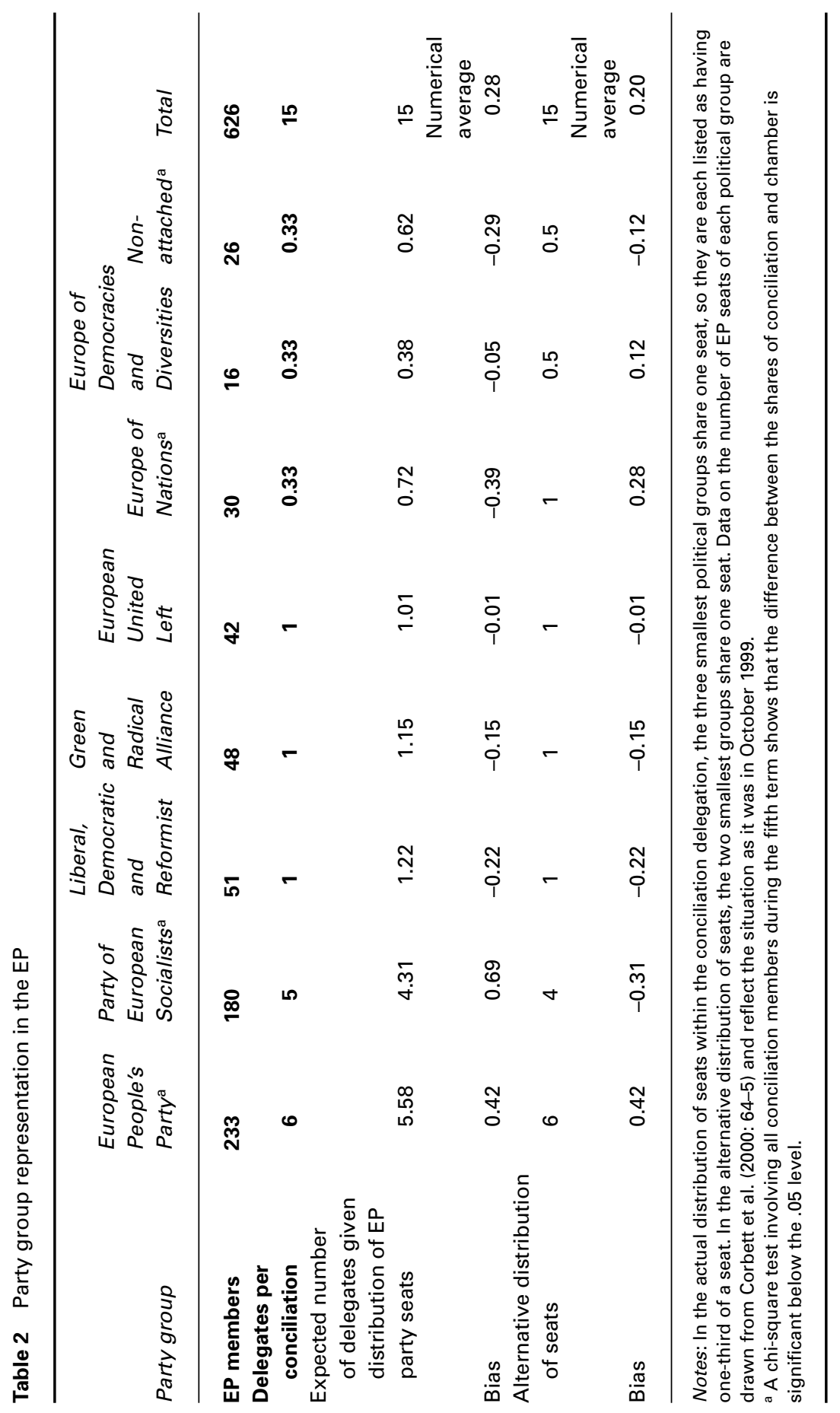


Table 3 How representative are the conciliation delegates of their party groups?

\begin{tabular}{|c|c|c|}
\hline Party group & $P P E$ & $P S E$ \\
\hline $\begin{array}{l}\text { Average numerical NOMINATE distance in the } 86 \text { procedures } \\
\text { between medians of party group members of the delegation } \\
\text { and party group members of the entire chamber }\end{array}$ & 0.0239 & 0.0278 \\
\hline $\begin{array}{l}\text { Percentage share of the } 86 \text { procedures where the } \\
\text { Wilcoxon-Mann-Whitney test shows that the } \\
\text { difference is significant below the } .05 \text { level }\end{array}$ & $4.7 \%$ & $2.3 \%$ \\
\hline $\begin{array}{l}\text { Average numerical NOMINATE distance in the } 86 \text { procedures } \\
\text { between medians of party group members of the delegation } \\
\text { and the entire chamber }\end{array}$ & 0.4836 & 0.4007 \\
\hline
\end{tabular}

Note: $N=$ chamber members and 946 PPE and PSE conciliation delegates in 86 conciliation committees.

a high coherence between the policy position of the party group delegates and the group as a whole in the plenary. Taking into account that party groups are likely to be somewhat constrained in appointing a representative delegation by having only a few members in each delegation, as well as having to respect the practice that most members come from the relevant standing committee and that the rapporteur, chairperson and three vice-presidents responsible for conciliation are always appointed, the ideological cohesion found between them and their conciliation members is remarkably high.

\section{Country principal}

Finally, I estimate the extent to which conciliation members act as agents of their fellow national members in the EP. Firstly, I examine whether countries are represented in a similar way in the delegations and in the chamber (Table 4). Starting with the big countries, the proportions of Germans in conciliation and in the chamber are almost equal, the British are overrepresented, and the French, Italians and Spaniards are underrepresented. Among the smaller countries, the Netherlands, Sweden and Greece are overrepresented, Ireland, Luxembourg and Portugal are underrepresented, and Austria, Belgium, Denmark and Finland lie somewhere in between. Statistical tests involving all conciliation delegates in the period show that for 9 of the 15 countries there are significant differences between the proportion of full conciliation delegates and the entire EP. The figures underline that strict national representation might in practice be impossible to achieve. Hence, member states with a relatively high share of members in the two large groups 
Table 4 Country representation in the EP

\begin{tabular}{|c|c|c|c|}
\hline Country & $\begin{array}{l}\text { Conciliation } \\
\text { delegates (No.) }\end{array}$ & Share (\%) & EP share (\%) \\
\hline Austria & 44 & 3.49 & 3.35 \\
\hline Belgium & 43 & 3.41 & 3.99 \\
\hline Denmark & 37 & 2.94 & 2.56 \\
\hline Finland & 26 & 2.06 & 2.56 \\
\hline France $^{a}$ & 132 & 10.48 & 13.90 \\
\hline Germany & 199 & 15.79 & 15.81 \\
\hline Greece $^{a}$ & 85 & 6.75 & 3.99 \\
\hline Ireland ${ }^{\mathrm{a}}$ & 19 & 1.51 & 2.40 \\
\hline Italy & 151 & 11.98 & 13.90 \\
\hline Luxembourg $^{a}$ & 2 & 0.16 & 0.96 \\
\hline Netherlands ${ }^{a}$ & 107 & 8.49 & 4.95 \\
\hline Portugala & 20 & 1.59 & 3.99 \\
\hline Spain ${ }^{a}$ & 94 & 7.46 & 10.22 \\
\hline Sweden ${ }^{a}$ & 76 & 6.03 & 3.51 \\
\hline United Kingdoma & 225 & 17.86 & 13.90 \\
\hline Total & 1260 & 100.00 & 100.00 \\
\hline
\end{tabular}

and committees that often go to conciliation are also likely to be overrepresented here.

One possibility for national members to use the Conciliation Committee strategically to promote national interests would be to attempt to become overrepresented in delegations that negotiate cases where national interests play a large role and that are of vital interest to their country. Two such examples are the resale rights directive (COD 1996 85) and the first takeover proposal (COD 1995 341). In the first of these, national differences in whether and how resale rights for artists were already recognized were important, and a closer examination of my data shows that MEPs from countries in favour of EU-wide resale rights (for example Germany and Spain) were overrepresented in the delegation. On takeovers, the Commission (2002: 9) has also pointed out that one reason the conciliation text failed to get confirmed by the plenary was that the delegation overrepresented German, UK and Spanish members even though differences in national corporate culture were at stake. Hence, in a subset of cases where national differences cut across party 
lines, MEPs from affected countries may be able to place themselves strategically in conciliation. However, whether they succeed depends on how many members from a country who have the relevant expertise sit on the relevant standing committee, etc. Moreover, having a disproportionate share of the conciliation delegates is not necessarily enough also to exert a disproportionate influence on the policy, because conciliations are kept under tight control by the chamber (Rasmussen, 2005). Finally, even though MEPs from countries with a high stake in a proposal may succeed in getting overrepresented, it is likely that some of these will have views that balance each other out, so that the delegation is still representative of the full plenary. This was the case, for example, in the takeover proposal mentioned. Despite the fact that the conciliation delegation adopted the deal and the plenary rejected it, the votes in both the plenary and the delegation were very similar, i.e. a perfect, or very close to, two-way split (European Parliament, 2001a: 14).

The second stage of the test looks at how representative the policy positions of the conciliation members from a given country were of all the members from that country in the full legislative body. Small countries have not necessarily had a lot of members who have served in conciliation, so I limited the calculation to the big countries. The figures in Table 5 show that there is a certain degree of coherence between conciliation delegates and their national groups as a whole. Only in Italy and the United Kingdom are significant differences found in a very small minority of the conciliation procedures between the members from a country in the EP and the country's members appointed as conciliation delegates. Again, however, it would be unrealistic to expect a lot of significant differences because each country has only a small $n$ on each conciliation delegation.

Instead, I look at the average numerical NOMINATE distance in the procedures between the medians of conciliation members from a given country and all country members in the EP. The smaller this distance is, the more representative conciliation delegates are of their country. The calculations show that there is some discrepancy, especially for Italy. Moreover, it can be seen that the average numerical distances are generally much larger than those between the conciliation delegates and any of their other potential principals examined here. This reflects the fact that no national groups cut across the parties within the EP and thus also no 'country coordinators' within the standing committees who could control the ideological position of the members from a given country are appointed as conciliation delegates. Thus, if a country is represented by either high-demand or low-demand members in comparison with a country median, this is likely to be by accident.

In fact, the distance between the median of the conciliation delegates from a given country and the median of all country members in the EP is typically 
Table 5 How representative are the conciliation delegates of their fellow country members in the EP?

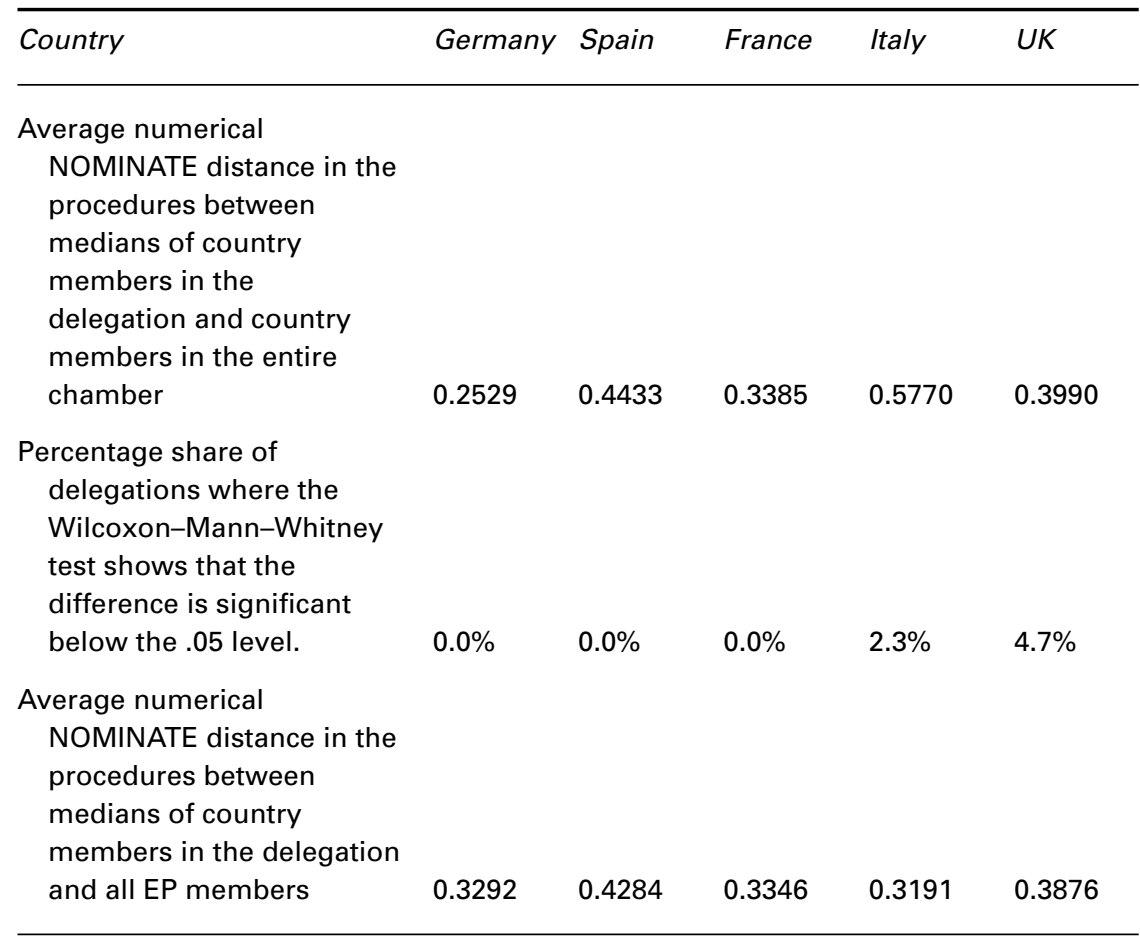

Note: $N$ = chamber members and 801 conciliation delegates from Germany, Spain, France, Italy and the UK in 86 conciliation procedures.

similar to the distance between the median of the country's conciliation delegates and the chamber median. Of the five countries, Germany is the only one with a clear trend showing that the median of the conciliation delegates is on average closer to that of all German MEPs than to the chamber median. For Italy, the result is the exact opposite: the conciliation delegates are on average closer to the chamber median than to that of all Italian MEPs. For the UK, France and Spain, the delegates are approximately as close to the chamber median as to the median of their country members in the EP. Measured on the left/right scale, it is thus not the case that MEPs from certain member states in conciliation, and the rest of the chamber, have coherent ideological positions.

Defenders of a national perspective might argue that it is not reasonable to use a left/right scale to assess national representativeness, but that national MEPs may be cohesive in another dimension such as pro-/anti-European 
integration. The argument would be that in harmonization of internal market measures, for example, MEPs with similar national regulation have similar policy views. To ascertain whether this holds, I conducted the same analysis for the second-dimension NOMINATES, which according to Hix et al. (2006) have been used to represent government-opposition conflicts as well pro/anti-Europe attitudes. Even in this dimension, however, the average NOMINATE distance in the 86 procedures between a party group and its conciliation delegates is still considerably lower than the distance between conciliation members from a given country and all country members in the plenary.

\section{Conclusion}

The EU Conciliation Committee has received very little attention in academic literature, despite its ability to present take-it-or-leave-it offers to its parent legislative bodies at the end of the legislative process and the fact that it negotiates important legislation with substantial effects on EU citizens. This analysis gives us some first insights into the interests of the potential principals who comprise the EU Conciliation Committee. Only the EP delegation was examined, because the Council delegation cannot reasonably be expected to have an incentive to deviate from the overall position of the Council.

In the EP, the tests for the different principals involved two key questions: (a) is a certain group (standing committee, party group, group of country members in the EP) overrepresented or underrepresented, and (b) are the policy positions of the delegates representative of a given principal? Looking at representation, the share of MEPs from different countries was random, whereas there was a systematic overrepresentation in conciliation of members of the previous standing committees as well as some overrepresentation of the big party groups. However, a look at the policy positions reveals that these overrepresentations do not lead to any distortions in the policy composition of the conciliation delegation. The overrepresentation of the two largest groups is not very strong and the PPE and the PSE groups balance each other out because they are at opposite ends of the policy scale. Moreover, the overrepresentation of the standing committees does not play a large role because these committees are representative of the EP itself. Thus, it was shown that distributional theory did not have any explanatory power, whereas informational theory performed well in predicting the composition of the EP conciliation delegation, which was typically only marginally biased. Moreover, despite the EU being a union of states, there was also no evidence that conciliation delegates represent the policy views of all members of their 
country as a whole. Instead, the representational ratios and ideological composition of the EP conciliation delegation ensure that the delegates represent both their party groups and the chamber as whole. Therefore, the option to go to conciliation should not generally be seen as a risky means for the EP to reach agreement. The EP and the Council may still wish to try to avoid going to conciliation. However, this is more likely to be motivated by other reasons such as to save time and energy by concluding early in the legislative process than by a fear that going to conciliation involves the risk that the delegates will shift the legislative outcomes away from their preferences.

There might be several reasons why the EP's conciliation delegation is not more biased than it is. Rasmussen (2005) points to the effectiveness of the appointment rules. This is confirmed here. Thus, we saw that, even though there is no rule similar to that of the US House of Representatives requiring that the majority of the conciliation delegates previously supported the EP position, this is the case in practice. The analysis showed that the party groups do not send party outliers to conciliation but send members who are representative of the group as a whole. There may be additional reasons the EP conciliation delegation is as representative as it is. First, the EP has no need to appoint an extreme delegation to try to counterbalance an extreme Council delegation. As mentioned, the Council delegation is composed in such a way that it is never extreme. It is the Council. One might think that a parliament could still try to appoint an extreme delegation to move the Council towards its end of the continuum, but here the EP is a special case.

Hence, a second reason the EP does not appoint an extreme delegation is that this would create the risk that the compromises agreed with the Council would not get adopted by the plenary afterwards. Hence, ordinary MEPs are not likely to be able to see a strategic advantage in having an extreme delegation, but rather are likely to react negatively if they find out that conciliation delegates are defending more extreme points than those agreed in the second reading amendments of the EP. If too many conciliation compromises failed to get adopted by the EP plenary, there would be a real risk that it would not be regarded as a serious partner to negotiate with, which could have consequences for the willingness of the member states to extend the scope of co-decision. This emerges very clearly in one of the EP's own reports, which states: 'The credibility and representativeness of the delegation have been one of Parliament's assets, even in cases where the Conciliation Committee attendance of MEPs has been limited' (European Parliament, 1999: 6-7). Moreover, it would not be the first time that the EP has decided to restrict itself in order to act effectively in inter-institutional negotiations, which is for example also the case with restrictions that it has taken on when tabling second reading amendments (European Parliament, 2005: rule 62). 


\section{Notes}

I would like to thank Yosef Bhatti for research assistance and to acknowledge financial support from the European Commission. I would also like to thank Bernard Steunenberg, Arndt Wonka and three anonymous reviewers for comments on an earlier draft.

1 The country in charge of the six-month rotating EU presidency is represented by the minister responsible for the area being negotiated.

2 Typically, a qualified majority if the European Commission supports the EP's amendments, otherwise unanimity. There are currently three Treaty articles where unanimity in the Council is always required. Article 251 of the Treaty sets out the co-decision procedure.

3 The Treaty merely states that a joint text has to be adopted by a majority (emphasis added) of the EP representatives, and it is unclear whether this means a simple or an absolute majority. After the failure of the takeover directive, however, the legal service of the EP clarified that the delegation needs not merely a simple but an absolute majority to adopt the joint text (European Parliament, 2001a: 15).

4 Both interviews were conducted in September 2004.

5 The approach adopted by other authors, namely of testing the theories against each other, has been adopted here too. However, note that, strictly speaking, their assumptions on policy context are incompatible in some respects. For example, informational theory assumes a one-dimensional policy space, whereas distributional theory assumes multiple dimensions to which actors attach different salience.

6 The names of the parliamentary conciliation delegates have been obtained from the archives of the EP's Conciliation Secretariat. Because substitute members in the EP do not have voting rights unless the full members cannot participate, they are not included in the tables here.

7 I use the W-NOMINATE score even though it is non-dynamic (i.e. the actual scores cannot be compared over time between different Parliaments or between different legislative bodies), which is not a problem here where I look at only one legislative body and one term.

8 Biotechnology (COD 1994 159) refers to the only file in the fourth session of the EP (1994-9) that was rejected by the plenary of the EP after a conciliation report had been agreed with the Council.

9 Information about the composition of the EP's standing committees was gathered from European Parliament (2001b).

\section{References}

Carruba, Clifford J., Matthew Gabel, Lacey Murrah, Ryan Clough, Elizabeth Montgomery and Rebecca Schambach (2006) 'Off the Record: Unrecorded Legislative Votes, Selection Bias, and Roll-Call Vote Analysis', British Journal of Political Science 36(4): 691-704. 
Commission (2000) 'The Co-decision Procedure. An Information Note on the Operation of the Co-decision Procedure from Maastricht to Amsterdam', internal note.

Commission (2002) 'Codecision November 1993 to November 2002. An Analysis'.

Corbett, Richard, Francis Jacobs and Michael Shackleton (2000) The European Parliament, 4th edn. London: John Harper Publishing.

Cox, Gary W. and Mathew D. McCubbins (1993) Legislative Leviathan. Party Government in the House. Berkeley: University of California Press.

Cox, Gary W. and Mathew D. McCubbins (1994) 'Bonding, Structure and the Stability of Political Parties: Party Government in the House', Legislative Studies Quarterly 19(2): 215-31.

Davidson, Roger H. and Walter J. Oleszek (2002) Congress and Its Members. Washington DC: Congressional Quarterly Press.

European Parliament (1996) 'Delegations to the Conciliation Committee: Progress Report 1 March 1995 to 31 July 1996', PE 216.734.

European Parliament (1999) 'Delegations to the Conciliation Committee: Activity Report 1 November 1993-30 April 1999', PE 230.998.

European Parliament (2001a) 'Delegations to the Conciliation Committee: Activity Report 1 August 2000 to 31 July 2001', PE 287.593.

European Parliament (2001b) 'List of Members'. Luxembourg: Office des publications officielles des Communautés européennes.

European Parliament (2005) Rules of Procedure, 16th edn, updated September.

Farrell, Henry and Adrienne Héritier (2003) 'The Invisible Transformation of Codecision: Problems of Democratic Legitimacy', Swedish Institute for European Policy Studies, No. 7.

Garman, Julie and Louise Hilditch (1998) 'Behind the Scenes: An Examination of the Importance of Informal Processes at Work in Conciliation', Journal of European Public Policy 5(2): 271-84.

Hix, Simon, Abdul Noury and Gérald Roland (2006) 'Dimensions of Politics in the European Parliament', American Journal of Political Science 50(2): 494-511.

Hoyland, Björn (2006) 'A Second Look at Roll Call Voting in the European Parliament', paper presented at the meeting of the European Legislative Politics Research Group, 20-21 October, Uppsala.

Jewell, Malcolm E. and Samuel C. Patterson (1986) Legislative Process in the United States, 4th edn. New York: Random House.

Kiewiet, D. Roderick and Mathew D. McCubbins (1991) The Logic of Delegation. Chicago, IL: University of Chicago Press.

König, Thomas, Björn Lindberg, Sandra Lechner and Winfried Pohlmeier (2007) 'Bicameral Conflict Resolution in the European Union. An Empirical Analysis of Conciliation Committee Bargains', British Journal of Political Science 37(2): 281-312.

Krehbiel, Keith (1991) Information and Legislative Organization. Ann Arbor: University of Michigan Press.

McElroy, Gail (2006) 'Committee Representation in the European Parliament', European Union Politics 7(1): 5-29.

McElroy, Gail (2007) 'Legislative Politics', in Knud Erik Jorgensen, Mark Pollack and Ben J. Rosamond (eds) Handbook of European Union Politics, pp. 175-94. London: Sage Publications. 
Maltzman, Forrest (1997) Competing Principals. Committees, Parties and the Organization of Congress. Ann Arbor: University of Michigan Press.

Napel, Stefan and Mika Widgren (2003) 'Bargaining and Distribution of Power in the EU's Conciliation Committee', Cesifo Working Paper No. 1029.

Poole, Keith T. and Howard Rosenthal (1997) Congress: A Political-Economic History of Roll Call Voting. New York: Oxford University Press.

Rasmussen, Anne (2005) 'EU Conciliation Delegates - Responsible or Runaway Agents? - Principal-agent analysis and the study of delegation', West European Politics 28(5): 1015-34.

Rybicki, Elizabeth, Steven S. Smith and Ryan Vander Wielen (2003) 'Congressional Conference Committee Bias, 1963-2002: A Preliminary Investigation', paper presented at the Annual Meeting of the American Political Science Association, 27-31 August, Philadelphia.

Shackleton, Michael (2000) 'The Politics of Codecision', Journal of Common Market Studies 38(2): 325-42.

Shepsle, Kenneth and Barry Weingast (1987a) 'The Institutional Foundations of Committee Power', American Political Science Review 81(1): 85-104.

Shepsle, Kenneth, and Barry Weingast (1987b) 'Why Are Congressional Committees Powerful?', American Political Science Review 81(3): 929-45.

Strøm, Kaare (2003) 'Parliamentary Democracy and Delegation', in Kaare Ström, Wolfgang C. Müller and Torbjörn Bergman (eds) Delegation and Accountability in Parliamentary Democracies, pp. 55-107. Oxford: Oxford University Press.

Tsebelis, George and Jeannette Money (1997) Bicameralism. Cambridge: Cambridge University Press.

Weingast, Barry R. and William J. Marshall (1988) 'The Industrial Organization of Congress: Or Why Legislatures, Like Firms, Are Not Organized as Markets', Journal of Political Economy 96(1): 132-63.

Whitaker, Richard (2005) 'National Parties in the European Parliament: An Influence in the Committee System', European Union Politics 6(1): 5-28.

\section{About the author}

Anne Rasmussen is Max Weber Fellow at the European University Institute and Assistant Professor at the Copenhagen Business School, European University Institute, Villa La Fonte, Via delle Fontanelle, 20, I-50014 San Domenico di Fiesole (FI), Italy.

Fax: +39055 4685804

E-mail: anne.rasmussen@eui.eu 